\title{
Properties of Choroid and Ciliary Neurons in the Avian Ciliary Ganglion and Evidence for Substance $P$ as a Neurotransmitter ${ }^{1}$
}

\author{
STUART E. DRYER AND VINCENT A. CHIAPPINELLI ${ }^{2}$ \\ Department of Pharmacology, St. Louis University School of Medicine, St. Louis, Missouri 63104
}

\begin{abstract}
Intracellular recordings were made from identified choroid and ciliary neurons in the ciliary ganglion of the embryonic chick. Choroid neurons, which were innervated by multiple preganglionic fibers, frequently displayed noncholinergic slow excitatory postsynaptic potentials (EPSPs) following repetitive stimulation of the preganglionic nerve trunk. These slow potentials were blocked by high $\mathrm{Mg}^{2+} / \mathrm{low} \mathrm{Ca}^{2+}$ buffer and were closely mimicked by bath application of substance $P$, which is known to be present within both populations of preganglionic nerve terminals. Substance P-induced depolarizations desensitized during prolonged exposure, at which time it was no longer possible to evoke slow synaptic potentials. Following manual voltage clamp to resting membrane potential, parallel increases in input resistance were seen during the slow EPSP and the response to substance P, suggesting that the two responses share common mechanisms.

Ciliary neurons, which were innervated by a single preganglionic fiber and displayed dual electrical-chemical synapses, did not exhibit slow synaptic potentials and were unaffected by bath application of substance $P$. The magnitude and time course of fast nicotinic EPSPs elicited in ciliary neurons by $0.5 \mathrm{~Hz}$ presynaptic stimulation were also unchanged in the presence of 1 to $3 \mu \mathrm{m}$ substance $P$.

Although the ciliary and choroid neurons share a common embryological origin in the neural crest, they are specialized for quite different physiological roles. Integration of multiple presynaptic inputs occurs at choroid synapses, mediated by the presence of both subthreshold fast nicotinic EPSPs and the slow EPSP. In contrast, synapses on ciliary neurons have specializations which preclude any integrative function, including single innervation, a high quantal content, electrical coupling potentials, and a lack of slow synaptic potentials.
\end{abstract}

The avian ciliary ganglion is a simple model system for the study of synaptic transmission (reviewed by Pilar and Tuttle, 1982). All known preganglionic fibers originate in the Edinger-Westphal nucleus (Cowan and Wenger, 1968) and enter the ganglion via the oculomotor nerve, whereas postganglionic fibers course through the ciliary and choroid nerves to innervate the choroid, ciliary, and iris muscles.

Several elegant studies by Martin and Pilar (1963a, b, 1964) have

Received September 24, 1984; Revised April 1, 1985;

Accepted April 3, 1985

${ }^{1}$ This work was supported in part by National Institutes of Health Grant NS17574 to V. A. C. We wish to thank Kathleen Wolf for preparing the figures and l.inda Russell for typing the manuscript

${ }^{2}$ To whom correspondence should be addressed. demonstrated the existence of mixed electrical-chemical synapses in the avian ciliary ganglion. These have included intracellular recordings from both ganglion cells and presynaptic nerve terminals (Martin and Pilar, 1963a, 1964a), as well as extracellular recordings from the ciliary nerves (Martin and Pilar, 1963b). Electrical transmission has been associated with unusual, large calyciform nerve terminals in this preparation (Martin and Pilar, 1963a). These terminals, which are found only on the large-cell population of Hess (1965), are further characterized by the presence of circumsynaptic myelin lamellae (Hess, 1965; Hess et al., 1969) and gap junctions (Cantino and Mugnaini, 1975). In contrast, synapses on the small-cell population display typical bouton endings associated with purely chemical synaptic transmission (Hcss, 1965; Marwitt et al., 1971). Pilar and his colleagues (Marwitt et al., 1971) have determined that the large cells project to the striated muscle of the iris and ciliary bodies by way of the ciliary nerves, and they have referred to this population as ciliary neurons. The smaller cells, or choroid neurons, were found to project via the choroid nerves to the smooth muscle choroidal coat of the eye.

More recently, substance P-like immunoreactivity has been localized in cell bodies within the Edinger-Westphal nucleus (Erichsen et al., 1982b) and in both calyciform and bouton nerve terminals within the avian ciliary ganglion (Erichsen et al., 1982a, b). Electron micro graphs have revealed that, in these terminals, the substance P-like immunoreactivity is associated with a population of dense-core synaptic vesicles and is co-localized with acetylcholine.

The purpose of the present study was to examine slow synaptic transmission, patterns of preganglionic innervation, and the actions of substance $P$ at synapses on the choroid and ciliary neurons in the avian ciliary ganglion. We now report that substance $P$ closely mimics a slow, noncholinergic excitatory postsynaptic potential (EPSP) which we have identified in the choroid cells. In contrast, substance $P$ has no detectable effect on ciliary cells, which also do not exhibit slow EPSPs.

\section{Materials and Methods}

The methods used for obtaining intracellular recordings from units in the avian ciliary ganglion have been described previously (Dryer and Chiappinelli, 1983). In brief, the ciliary ganglion was dissected from White Leghorn (SPAFAS, Peoria IL) chick embryos (18 to 20 days of incubation); the external capsule was completely removed and the ganglion was pinned out in a small chamber coated with cured Sylgard resin. The preparation was superfused at 3 to $5 \mathrm{ml} / \mathrm{min}$ with a Tyrode's solution of the following composition: $\mathrm{NaCl}$ (150 mM), $\mathrm{KCl}(4 \mathrm{~mm}), \mathrm{CaCl}_{2}(5 \mathrm{~mm}), \mathrm{MgCl}_{2}$ (2 mM), Tris (10 mM), glucose $(11 \mathrm{~mm}), \mathrm{pH} 7.4$, and was warmed to $37^{\circ} \mathrm{C}$. Standard bridge balance methods were used to pass square current pulses or DC current through glass microelectrodes (60 to 160 megohms) filled with $3 \mathrm{M} \mathrm{KCl}$. Bridge balance was determined following withdrawal of the recording electrode from the cell by means of 50- to 90-msec current pulses. These pulses were long enough to allow capacitative artifacts to decay completely. Membrane potential was also determined upon withdrawal of the electrode. Records were displayed on an oscilloscope and photographed. Preganglionic nerve stimuli were 
delivered by means of a glass suction electrode placed on the oculomotor nerve.

In most cases, drugs were applied by gravity-fed superfusion from reservoirs controlled by electric valves. Dead time was 15 to $30 \mathrm{sec}$. Occasionally, agonists were pressure injected from small glass recording electrodes (broken back under visual control) by means of nitrogen gas (20 p.s.i.) and an electrically activated solenoid valve. Alternatively, drugs were injected manually from a pressure pipette placed $3 \mathrm{~mm}$ "upstream" from the ganglion (Dryer and Chiappinelli, 1983).

The choroid cells are located in the dorsal, distal quadrant of the ganglion (Hess, 1965). We had the greatest success impaling choroid cells when the ganglion was pinned out such that the stumps of the choroid nerves could be directly obscrvod on the top of the preparation (Fig. 1). Under these conditions the choroid cell region had a slightly more translucent appearance than did the remainder of the ganglion. Most choroid cells were impaled in regions immediately adjacent to the choroid nerve trunks. Impalements of ciliary cells were most frequent in regions of the ganglion characterized by a more opaque, granular appearance. A postsynaptic cell was analyzed only if its resting membrane potential was greater than $-40 \mathrm{mV}$, if it fired overshooting regenerative action potentials with a rheobase of less than 1 $\mathrm{nA}$, and if it could be unambiguously identified as either a ciliary cell or a choroid cell

\section{Results}

The results of this study are from 65 cells in 20 preparations of the chick ciliary ganglion.

Criteria for identification of units. In most cells unambiguous identification was not difficult. Martin and Pilar (1963a) have previously shown that ciliary cells are innervated by a single preganglionic fiber with a mixed electrical-chemical synapse. In agreement with this previous study, preganglionic stimulation produced an all-ornone action potential with a minimal latency in ciliary cells. When nerve stimulation was superimposed on a hyperpolarizing current pulse, an electrical coupling potcntial, followed by a chemical EPSP, was observed (Fig. 2A). Both components were all-or-none. Ciliary cells could fire action potentials following orthodromic or direct intracellular stimulation at high rates, in some cases up to $100 \mathrm{~Hz}$.

Choroid cells were not electrically coupled. The latency of synaptic

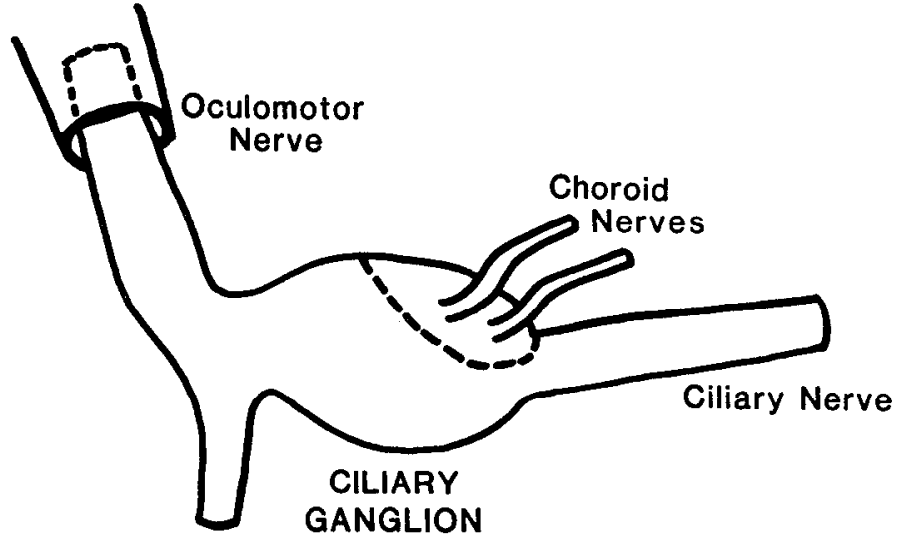

Figure 1. Diagram of the preparation. A suction electrode is stown on the preganglionic oculomotor nerve. In order to impale choroid neurons, the ganglion was pinned out with the stumps of the choroid nerves visible on the top surtace of the ganglion. Ihe microelectrode was then positioned in the quadrant of the ganglion nearest the choroid nerves (denoted by the dashed line). Ciliary neuron impalements were most frequent in the regions of the ganglion outside this quadrant.

transmission was considerably longer than in ciliary cells, and action potentials would occasionally fail, leaving a subthreshold chemical EPSP (Fig. 2B). This was best seen at low stimulus intensities or at frequencies greater than $15 \mathrm{~Hz}$. When preganglionic stimulation was superimposed upon a hyperpolarizing current pulse, a chemical EPSP was seen, but no electrical coupling potential was detected. In most cases this EPSP could be graded with preganglionic stimulus intensity, indicating that choroid cells can be multiply innervated (Fig $2 B$ ). We have recruited between one and four inputs per cell in 32 choroid cells tested. The majority $(80 \%)$ of cells appear to have two or three inputs. Choroid cells were unable to fire action potentials at

\section{A CILIARY NEURONS}
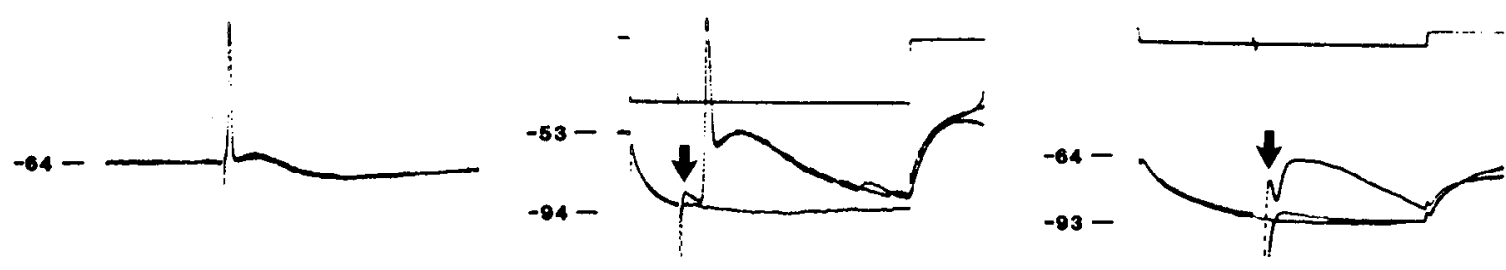

\section{B CHOROID NEURONS}
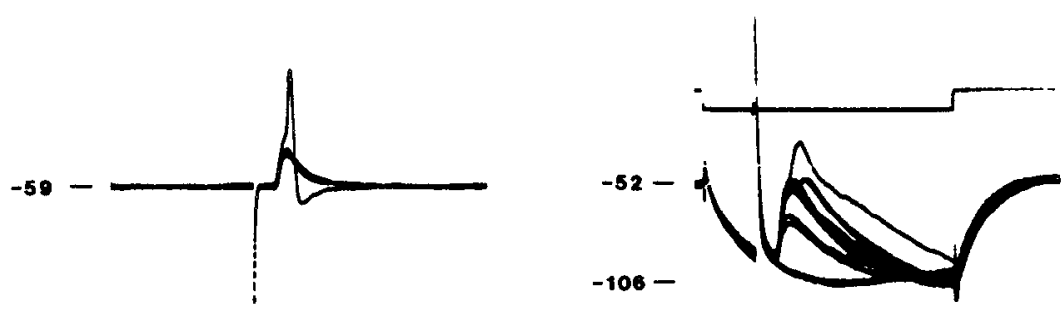

Figure 2. Criteria for identification of choroid and ciliary neurons in the avian ciliary ganglion. $A$, Orthodromic action potentials in ciliary neurons occur with minimal latency and do not display a chemical synaptic "hump" on the rising phase. When orthodromic stimulation is superimposed on a hyperpolarizing pulse, all-or-none electrical coupling potentials (arrows) are followed by suprathreshold or subthreshold nicotinic EPSPS. The all-or-none nature of these responses is shown by superimposing effective stimuli on top of failures, which were produced at a slightly lower stimulation intensity. $B$, Orthodromic stimulation at a single intensity (left) evokes either an action potential or a subthreshold nicotinic EPSP in choroid neurons. Note the chemical synaptic "hump" on the rising phase of the action potential. When orthodromic stimulation is superimposed on a hyperpolarizing pulse, a nicotinic EPSP is observed. Increasing the intensity of the preganglionic stimulus increases the size of the EPSP as additional preganglionic fibers are recruited (right). Calibration bars are (left to right); $A, 20 \mathrm{mV}$ and $5 \mathrm{msec} ; 0.25 \mathrm{nA}$ (top traces), $20 \mathrm{mV}$ (lower traces), and $5 \mathrm{msec}$; and $1 \mathrm{nA}, 20 \mathrm{mV}$, and $2 \mathrm{msec} ; B, 20 \mathrm{mV}$ and $5 \mathrm{msec}$; and $1 \mathrm{nA}, 20 \mathrm{mV}$, and $5 \mathrm{msec}$. In this and all subsequent figures relevant membrane potentials (in millivolts) are indicated at the left of each record. 
high frequency and usually began to fail following either orthodromic or direct intracellular stimulation at 20 to $30 \mathrm{~Hz}$.

Membrane properties of ciliary and choroid neurons. The input resistance of ciliary cells was lower than that of choroid cells, consistent with their larger size (Table I). Ciliary cells also had a significantly higher capacitance than did choroid cells (Table I). Both cell types had similar resting membrane potentials and spike configurations; in most cases the spike duration at half-amplitude was less than $1 \mathrm{msec}$, consistent with previous reports (Martin and Pilar, 1963a).

Responses to repetitive preganglionic stimulation. Repetitive preganglionic stimulation evoked slow depolarizations in 22 of 26 choroid cells tested (Fig. 3). These slow depolarizations lasted from $8 \mathrm{sec}$ to several minutes. At the peak of the depolarizations these slow EPSPs were variously associated with an increase, a decrease, or no change in input resistance. However, when the membrane potential was manually clamped back to the initial resting membrane potential, the slow depolarization was found to be associated with an increase in input resistance in 12 of 14 cells tested (Fig. $3 A$ ). The manual voltage clamp procedure is necessary to eliminate changes in input resistance secondary to the depolarization due to delayed or anomalous rectification (Katayama et al., 1979). In the two cells which failed to show an increase in input resistance, no change in input resistance was observed. The mean increase in input resistance (measured during manual clamp to resting membrane potential) was $18.4 \pm 4.5 \%$ (mean \pm SEM, $n=14$ ). The maximum depolarization observed during the slow EPSP in these same cells was 5.1 $\pm 0.6 \mathrm{mV}$ (mean $\pm \mathrm{SEM}, n=14$ ). These slow depolarizations could be evoked in the presence of either $3 \mu \mathrm{M}$ atropine (Fig. $3 B$ ) or 30 $\mu \mathrm{M} d$-tubocurarine (not shown), indicating that the slow EPSP was noncholinergic. Superfusion with Tyrode's solution containing 3.75 $\mathrm{mM} \mathrm{Mg}^{2+}$ and $0.25 \mathrm{mM} \mathrm{Ca}^{2+}$ reversably blocked slow EPSPS (Fig. $3 B$ ) and also abolished all fast chemical transmission (see Fig. 5B).

In some choroid neurons, the slow depolarizations appeared to be graded in parallel with the fast nicotinic EPSPs. In the example shown (Fig. 4), neither response was evoked by preganglionic nerve stimulation at $60 \mathrm{~V}$. Increasing the intensity of orthodromic stimulation to $110 \mathrm{~V}$ resulted in the appearance of both a slow depolarization and a fast nicotinic EPSP. A further step up to $150 \mathrm{~V}$ both increased the magnitude of the slow depolarization and recruited an additional input contributing to the nicotinic EPSP.

In contrast to the above results, no slow depolarizations were seen in any ciliary neurons following repetitive preganglionic stimulation (10 of 10 cells tested). Some ciliary neurons would respond with a brief post-train hyperpolarization followed by a return to the original membrane potential (see Fig. $6 A$ ).

Effects of substance $P$. Substance $P$ ( 1 to $3 \mu \mathrm{M}$ by superfusion) depolarized nearly all choroid cells tested (11 of 12; Fig. 5). This depolarization was associated with an increase in input resistance determined, as previously, during manual voltage clamp back to the resting potential ( 8 of 9 ; Fig. $5 A$ ). The mean increase in input resistance during the response to substance $P$ was $32.9 \pm 9.5 \%$ (mean \pm SEM, $n=9$ ). The maximum depolarization produced by substance $P$ in these same cells was $9.8 \pm 2.3 \mathrm{mV}$ (mean \pm SEM, $n=9$ ). At the maximum depolarization, spontaneous action potentials were sometimes seen (Fig. 5A). Following prolonged exposure to substance $\mathrm{P}$ ( 2 to $3 \mu \mathrm{M}$ ), the initial depolarization gradually faded,

TABLE I

Membrane properties of neurons in the avian ciliary ganglion

\begin{tabular}{lcccc}
\hline & $E_{\mathrm{m}}(\mathrm{mV})$ & $\mathrm{R}$ (megohms) & $\tau(\mathrm{msec})$ & $\mathrm{C}(\mathrm{pF})$ \\
\hline Ciliary neurons & $-58 \pm 4^{a}$ & $119 \pm 13$ & $6 \pm 1$ & $50 \pm 6$ \\
Choroid neurons & $-57 \pm 3$ & $244 \pm 11^{b}$ & $5 \pm 1$ & $23 \pm 3^{b}$ \\
\hline
\end{tabular}

${ }^{a}$ Values are mean $\pm \mathrm{SEM}, N=8$ cells in each group.

${ }^{b}$ Significant difference $(\rho<0.005)$ compared to ciliary neurons, as determined by the Student's unpaired $t$-test.
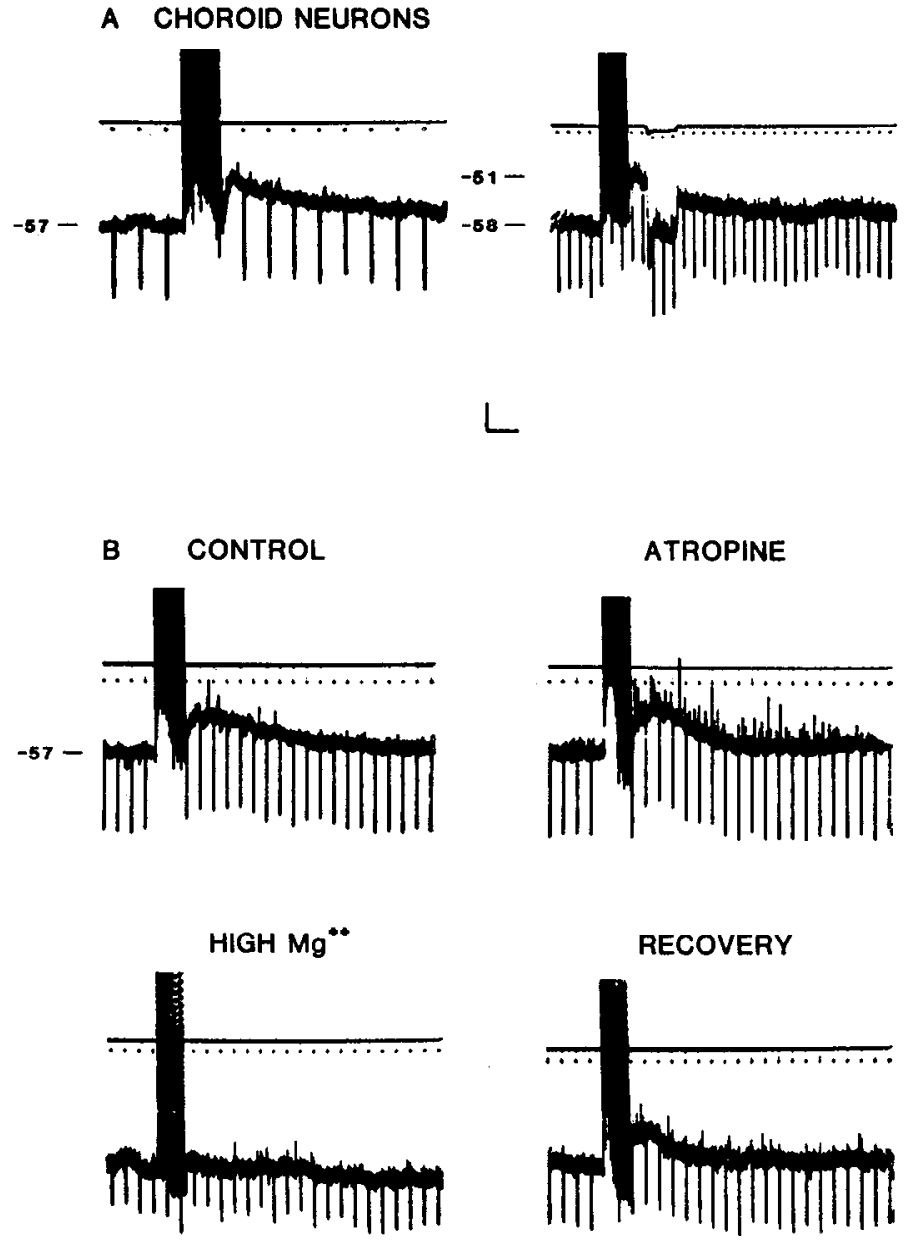

Figure 3. Slow synaptic potentials in choroid neurons. A, Repetitive preganglionic stimulation evokes a slow depolarization. Input resistance (measured as the voltage responses to constant hyperpolarizing current pulses) shows a slight increase at peak depolarization (left). This increase in input resistance persists during manual voltage clamp of membrane potential back to the resting level (right). $B$, slow synaptic potential in a different choroid neuron is unaffected by $10 \mathrm{~min}$ exposurc to $3 \mu \mathrm{M}$ atropine, but is reversably abolished by superfusion with Tyrode's solution containing 3.75 $\mathrm{mm} \mathrm{Mg}^{2+}$ and $0.25 \mathrm{mM} \mathrm{Ca}^{2+}$. Calibration bars are: $A$, left: $0.25 \mathrm{nA}, 5 \mathrm{mV}$, and $2 \mathrm{sec}, 30 \mathrm{~Hz}$ orthodromic stimulation, right: $0.25 \mathrm{nA}, 5 \mathrm{mV}$, and $5 \mathrm{sec}$, $20 \mathrm{~Hz}$ orthodromic stimulation. $B, 0.25 \mathrm{nA}, 5 \mathrm{mV}$, and $5 \mathrm{sec}, 30 \mathrm{~Hz}$ orthodromic stimulation for all records.

and the cell eventually returned to the original membrane potential. Moreover, when this occurred it was no longer possible to evoke slow EPSPs by repetitive preganglionic stimulation (Fig. 5C, 4 of 4 cells tested). Following a 10 - to 20 -min washout of substance $P, a$ partial recovery of the slow EPSP was seen.

The depolarizations induced by substance $P$ could be evoked in the presence of $3.75 \mathrm{mM} \mathrm{Mg}^{2+}$ and $0.25 \mathrm{mM} \mathrm{Ca}^{2+}$, conditions which abolished all synaptic transmission (Fig. $5 B, 3$ of 3 cells tested). The observed depolarizations are theretore caused by the direct actions of substance $P$ on the recorded cells and are not mediated by any actions of substance $P$ on adjacent neurons.

In seven choroid cells it was possible to examine both the response to substance $P$ and the slow EPSP in the same neuron. Input resistance during the responses was again determined during manual voltage clamp back to the resting potential. For each neuron, the increase in input resistance due to substance $P$ was plotted against the increase in input resistance due to the slow EPSP. The resulting points yielded a straight line (slope $=1.66, r^{2}=0.95, p<$ 


\section{A CHOROID NEURON}
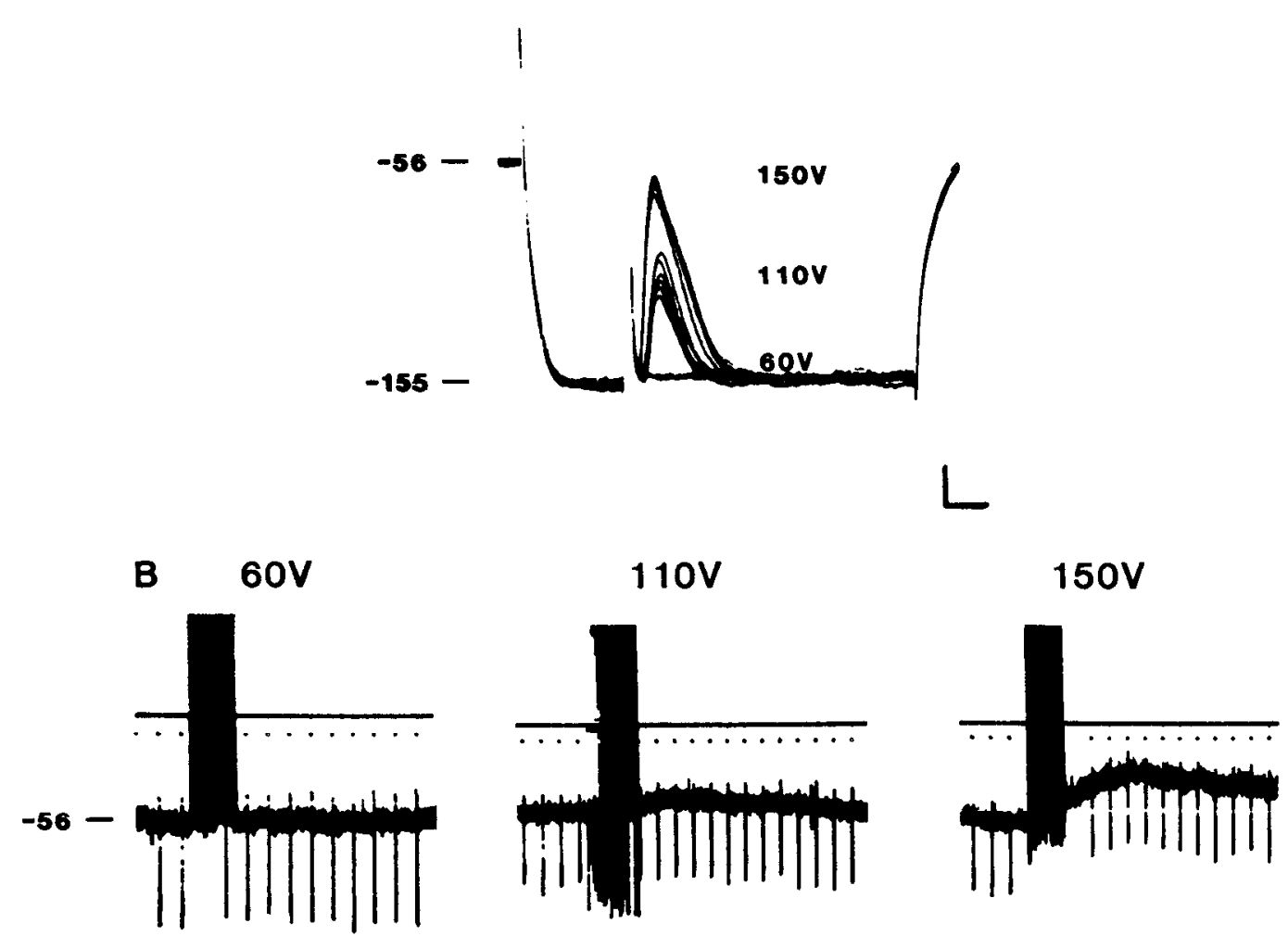

Figure 4. Grading of fast and slow EPSPS in a choroid neuron. A, Orthodromic stimulation is superimposed on a large hyperpolarizing current pulse. Stimulation at $60 \mathrm{~V}$ produces no nicotinic fast EPSP, whereas stimulation at $110 \mathrm{~V}$ reveals small nicotinic fast EPSPs. Increasing intensity to $150 \mathrm{~V}$ recruits an additional preganglionic input. $B$, In the same cell, repetitive orthodromic stimulation $(30 \mathrm{~Hz})$ at $60 \mathrm{~V}$ does not produce a slow EPSP. Stimulation at $110 \mathrm{~V}$ does produce a slow EPSP, whereas increasing the stimulus intensity to $150 \mathrm{~V}$ increases the amplitude of the slow EPSP. Calibration bars are: $A$, $20 \mathrm{mV}$ and $5 \mathrm{msec} ; B, 0.25 \mathrm{nA}, 5 \mathrm{mV}$, and $5 \mathrm{sec}$.

0.05 ), indicating that the response to substance $P$ and the slow EPSP may share similar conductance mechanisms.

Because the doses of substance $P$ used produced depolarizations and input resistance increases which were generally larger than those of the slow EPSPS, the data were normalized by calculating extrapolated equilibrium potentials according to the methods of Ginsborg et al. (1974), Adams and Brown (1975), and Dodd et al. (1981). In this approach the extrapolated equilibrium potential $\left(E_{\mathrm{eq}}\right)$ is given by

$$
E_{\mathrm{eq}}=\frac{R_{\mathrm{m}}}{R_{\mathrm{m}}-R_{\mathrm{m}}{ }^{*}} \Delta V+E_{\mathrm{m}}
$$

where $R_{\mathrm{m}}$ and $R_{\mathrm{m}}{ }^{*}$ are the membrane resistances measured in the absence and in the presence of the responses, respectively, $\Delta V$ is the depolarization caused by either substance $P$ or the EPSP, and $E_{\mathrm{m}}$ is the resting potential. In this case, $R_{\mathrm{m}}{ }^{*}$ was determined during martual voltage clamp to the resting potential. By this means we calculated a mean extrapolated equilibrium potential for the slow EPSP of $-85 \pm 3 \mathrm{mV}$ (mean $\pm \mathrm{SEM}, n=12$ ) and an extrapolated equilibrium potential for substance $P$ of $-89 \pm 5.2 \mathrm{mV}$ (mean \pm SEM, $n=8$ ). These results are not statistically different by the Student's unpaired $t$ test. These equilibrium potentials would be equivalent to reversal potentials if the current-voltage relationship were linear, if the chemosensitive conductances were unrelated to membrane potential, and if there were no errors in measurements of membrane potential or input resistance. These assumptions are either invalid or uncertain. Moreover, this method could not be used in the two cells where the depolarizations were not associated with a detectable change in input resistance, and these cells have been excluded from this analysis. For these reasons we refer to this measurement as an extrapolated equilibrium potential rather than a true reversal potential.

Substance P ( 1 to $3 \mu \mathrm{M}$ ) had no direct effect on any ciliary cells, a point which was tested by all three methods of drug delivery (14 of 14 cells; Fig. $6 B$ ). In addition, $2 \mu \mathrm{M}$ substance $P$ had no effect on the amplitude or rate of decay of nicotinic EPSPS elicited by preganglionic nerve stimulation at $0.5 \mathrm{~Hz}$ (Fig. 6C). As was the case for most ciliary neurons, it was not possible to pass enough hyperpolarizing current through the electrode to block the action potential shown in Figure $6 \mathrm{C}$. The presence of an action potential might possibly obscure some subtle effect of substance $P$ on the nicotinic EPSP, even though the responses seen before and during exposure to substance $P$ are clearly superimposable (Fig. $6 \mathrm{C}$, right).

\section{Discussion}

The avian ciliary ganglion contains two distinct cell types, the ciliary and choroid neurons, which share a common origin in the embryonic neural crest (Landmesser and Pilar, 1970, 1972; Marwitt et al., 1971). This common origin belies some striking differences observed between these two types of cells. For example, previous studies have shown that ciliary neurons are larger than choroid cells (Hess, 1965; Marwitt et al., 1971) and have a number of characteristics not found in the choroid neurons, including myelinated somata (Hess, 1965; Hess et al., 1969) gap junctions (Cantino and Mugnaini, 1975), and specialized presynaptic calyces capable of both electrical and chemical synaptic transmission (Martin and Pilar, 1963a, Hess et al., 1969). The results of the present study provide further evidence that these two cell types are specialized for quite different physiological roles.

Most of the previously published intracellular recordings in the 
avian ciliary ganglion have been from ciliary neurons. We have therefore examined the properties of choroid neurons in some detail. We find that most choroid cells are multiply innervated. Simultaneous activation of more than one preganglionic fiber is usually required to elicit an action potential in choroid cells. Single-fiber, fast nicotinic EPSPs are only slightly larger than spontaneous miniature EPSPS (not shown) and, therefore, the quantal content of a choroid cell fast EPSP is likely to be much smaller than that seen in ciliary neurons (discussed below). Since action potentials in a given preganglionic fiber do not necessarily evoke action potentials in postganglionic choroid neurons, spatial and temporal integration occurs at choroid synapses.

This type of integrative activity can be influenced by slow, nonnicotinic, synaptic potentials. These slow synaptic potentials have been observed in a wide variety of autonomic ganglia preparations (for review see Brown, 1983). The best studied example is the frog lumbar sympathetic ganglion. In this case, repetitive stimulation of the preganglionic fibers evokes a biphasic slow EPSP. The first phase, which is atropine sensitive, is followed by a prolonged depolarization thought to be mediated by a luteinizing hormonereleasing hormone (LHRH)-like peptide (Jan and Jan, 1983). Voltage clamp studies have shown that depolarization caused by muscarinic agonists, by LHRH-like peptides, and by the slow EPSP are all associated with inhibition of a time- and voltage-sensitive $\mathrm{K}^{+}$current called the M-current, and with activation of a poorly characterized inward current (Adams and Brown, 1980; Katayama and Nishi, 1982). The situation in the frog sympathetic ganglion is unusual in that slow EPSPs are observed in both singly (B cells) and multiply innervated (C cells) ganglion neurons (Nishi et al., 1965; Jan and Jan, 1983).

In the chick ciliary ganglion we have observed a similar slow EPSP in the multiply innervated choroid cells, where this response can be evoked by repetitive stimulation of proganglionic fibers $(5$ to $30 \mathrm{~Hz})$. This slow EPSP is associated with an increase in input resistance which is observed when the membrane is manually voltage-clamped back to the resting membrane potential. The fact that manual voltage clamp is required to consistently observe the increase in input resistance may be due to activation of persistent currents (such as delayed rectification) secondary to depolarization. This procedure is often necessary to obtain accurate input resistance measurements in neurons with markedly nonlinear current-voltage relationships (Katayama et al., 1979).

\section{A CHOROID NEURONS}

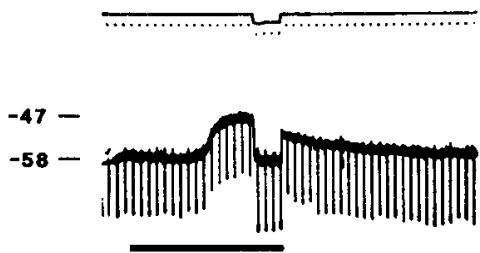

Sub P

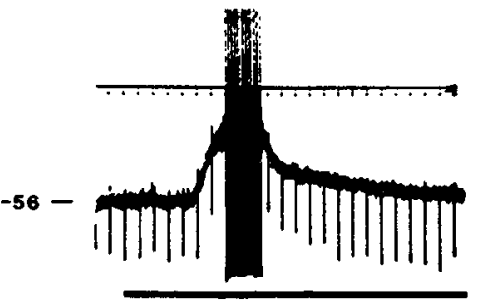

Sub $P$

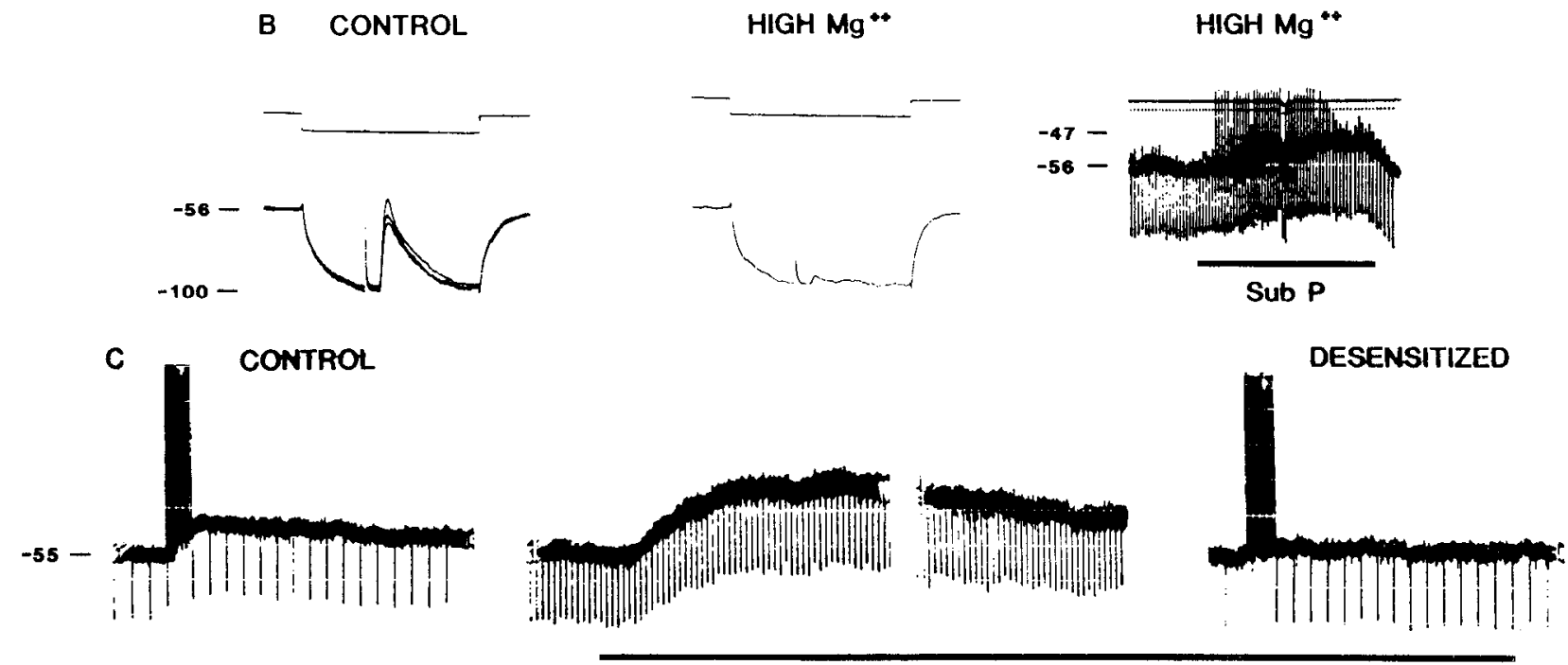

Sub P

Figure 5. Effects of substance $P$ on choroid neurons. A, Superfusion with Tyrode's solution containing $2 \mu \mathrm{M}$ substance $P$ (bars beneath records) evokes robust depolarization. Manual voltage clamp during the peak of depolarization (left) reveals increase in input resistance. Depolarization caused by superfusion with $2 \mu \mathrm{M}$ substance $\mathrm{P}$ can evoke spontaneous action potentials (right). The tops of the action potentials are cut off in this record. During continued exposure to substance $P$, the depolarization fades and the cell eventually returns to the original resting potential (right). $B$, Superfusion with Tyrode's solution containing $3.75 \mathrm{mM} \mathrm{Mg}^{2+}$ and $0.25 \mathrm{mM} \mathrm{Ca} \mathrm{a}^{2+}$ blocks fast synaptic transmission in a choroid neuron (center). In the same cell, superfusion with $2 \mu \mathrm{M}$ substance $\mathrm{P}$ dissolved in the same high $\mathrm{Mg}^{2+} / \mathrm{low} \mathrm{Ca}{ }^{2+}$ solution evokes a 9-mV depolarization (right). Anode break spikes appear in the record during the response to substance $P$. $C$. Repetitive orthodromic stimulation $(30 \mathrm{~Hz})$ evokes a slow depolarization in a choroid neuron (left). In the same cell, superfusion with Tyrode's solution containing substance $\mathrm{P}(3 \mu \mathrm{M})$ produces a depolarization which gradually fades during continuous exposure to the drug (middle two records). Depolarization eventually returns to the original resting membrane potential, at which time repetitive stimulation no longer evokes a slow depolarization (right). Calibration bars are: $A, 0.25 \mathrm{nA}, 10 \mathrm{mV}$, and $14 \mathrm{sec}$ (left) and $0.5 \mathrm{nA}, 10 \mathrm{mV}$, and $5 \mathrm{sec}$ (right); $B, 0.5 \mathrm{nA}, 20 \mathrm{mV}$, and $5 \mathrm{msec}$ (left and middle), and $0.25 \mathrm{nA}, 10 \mathrm{mV}$, and $20 \mathrm{sec}$ (right): $\mathrm{C}, 5 \mathrm{mV}$ and $2 \mathrm{sec}$ (left and right), and $5 \mathrm{mV}$ and $5 \mathrm{sec}$ (middle traces). 


\section{a ciliary neunons}

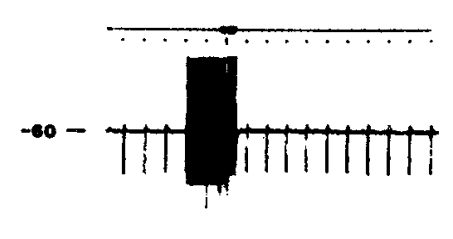

$\mathbf{B}$

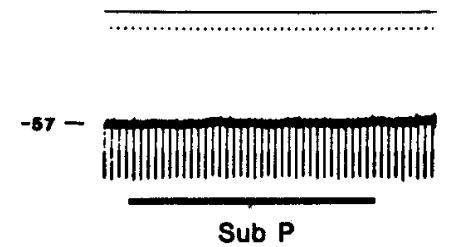

Sub $\mathbf{P}$

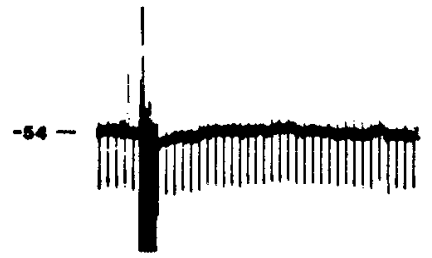

L

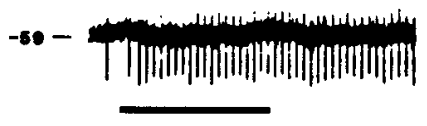

Sub P

Figure 6. Absence of slow synaptic potentials and lack of effect of substance $P$ in ciliary neurons. A, Repetitive orthodromic stimulation $(50 \mathrm{~Hz}$, left trace; $40 \mathrm{~Hz}$, right trace) does not produce a slow depolarization. Records show slight hyperpolarization inmedialely following cessation of repetitive stimulation. $B$, Superfusion with Tyrode's solution containing $2 \mu \mathrm{M}$ substance P (bars beneath records) does not affect membrane potential or input resistance in two different ciliary neurons. C, Superfusion with $2 \mu \mathrm{M}$ substance $\mathrm{P}$ had no effect on orthodromic transmission in a ciliary neuron (left and middle). In the same cell the decay phases of the nicotinic EPSPs are displayed on a digital oscilloscope (right). The two superimposed traces are in the presence and absence of $2 \mu \mathrm{M}$ substance $P$. Stimulation rate is $0.5 \mathrm{~Hz}$. Calibration bars arc: $A$, $1 \mathrm{nA}, 20 \mathrm{mV}$, and $2 \mathrm{sec}$, and $10 \mathrm{mV}$ and $5 \mathrm{sec}$ (current trace not shown); $B, 1 \mathrm{nA}, 20 \mathrm{mV}$, and 14 $\mathrm{sec}$, and $0.25 \mathrm{nA}, 5 \mathrm{mV}$, and $14 \mathrm{sec} ; \mathrm{C}, 1 \mathrm{nA}, 20$ $\mathrm{mV}$, and $5 \mathrm{msec}$ (left and middle). The grid on the right record is $12.5 \mathrm{mV}$ and $2.68 \mathrm{msec} /$ division.

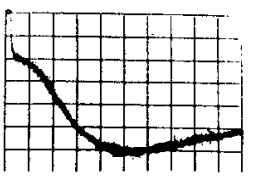

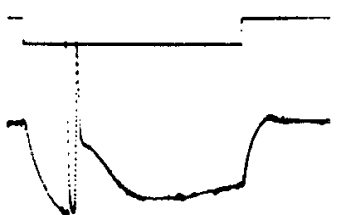

$-110-$

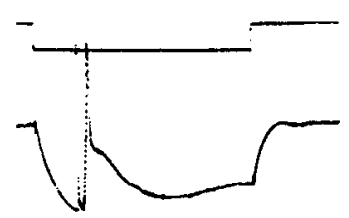

The slow EPSP is noncholinergic since it can be elicited in the presence of $3 \mu \mathrm{M}$ atropine or $30 \mu \mathrm{M} d$-tubocurarine, and there does not appear to be an "early-muscarinic" slow EPSP similar to that seen in the frog. The slow EPSP is blocked by superfusion with solutions containing $3.75 \mathrm{mM} \mathrm{Mg}^{2+}$ and $0.25 \mathrm{mM} \mathrm{Ca}^{2+}$; this also blocks fast nicotinic EPSPs and supports the notion that the slow EPSP is a synaptic event. Since the slow EPSPs can be graded with stimulus intensities in parallel with the fast nicotinic EPSPS, the same fibers are likely to be responsible for both responses. Recently Erichsen et al. (1982a, b) have determined that substance P-like immunoreactivity is located in nerve terminals synapsing on both choroid and ciliary cells in the avian ciliary ganglion. Electron microscopic observations reveal that substance P-like inmmunoreactivity and acetylcholine are co-localized in these terminals. Therefore, substance $P$ is a logical candidate for the mediator of the slow EPSPs.

Substance $\mathrm{P}$ depolarized nearly all of the choroid cells tested. These depolarizations persisted under conditions in which synaptic transmission was abolished. Substance $P$ depolarizations were associated with an increase in input resistance which, as previously, was seen following manual voltage clamp to the resting potential. Prolonged exposure to substance $P$ resulted in a desensitization which cvontually led to a return to the resting potential. During this desensitization to substance $P$, and in the continued presence of the peptide, the slow EPSP was abolished whereas nicotinic fast EPSPs were unaffected. The increases in resistance caused by substance $P$ paralleled the increases in resistance caused by the slow EPSP when both responses were tested in the same cell. Moreover, the two responses had a similar extrapolated equilibrium potential. These results demonstrate that substance $P$ and the slow EPSP utilize certain common mechanisms including, at least in part, inactivation of a $\mathrm{K}^{+}$conductance. Other studies have found similar effects of substance $P$ in amphibian (Adams et al., 1983) and mammalian (Dun and Minota, 1981; Otsuka and Konishi, 1983) sympathetic and mammalian enteric (Katayama et al., 1979) ganglia. In amphibian sympathetic ganglia the effects of substance $P$ have been specifically attributed to inhibition of the M-current (Adams et al., 1983); this point has not been ascertained in mammalian sym- pathetic ganglia, where activation of $\mathrm{Na}^{+}$currents has also been implicated (Dun and Minota, 1981). At present our data do not allow for identification of the exact ionic mechanisms underlying slow EPSPs in the choroid neurons. However, we do find that these slow EPSPs can contribute to integration in the choroid cells, since during the peak depolarization fewer preganglionic fibers are required to evoke action potentials in the postganglionic cells.

The properties of ciliary neurons in the avian ciliary ganglion are divergent in almost every regard from those of choroid neurons. Ciliary and choroid neurons differ in two passive membrane properties, namely, input resistance and capacitance. The mean input resistance of choroid cells (244 megohms) is nearly twice that oblained for ciliary cells (119 megohms). This difference is probably due to the smaller size of the choroid cells (Hess, 1965; Marwitt et al., 1971). Our value of ciliary neuron capacitance (50 pF) is in excellent agreement with the results of Martin and Pilar (1964a). In contrast, our value for choroid cell capacitance is only $23 \mathrm{pF}$, and this may be due to the smaller membrane surface area of choroid cells as well as to the absence of myelin sheaths. Brenner and Martin (1976) determined passive membrane properties of partially dissociated ciliary ganglion neurons and obtained values of input resistance and capacitance midway between our values for choroid and ciliary neurons. These investigators may therefore have sampled a mixed population of cells. Their reported time constant was identical to those reported here.

The ciliary neurons which we have impaled have all been singly innervated, confirming previous reports (Martin and Pilar, 1963a). Both nicotinic fast EPSPs and electrical coupling potentials are present in these neurons. The chemical component of synaptic transmission in ciliary cells has a very high quantal content compared to other autonomic ganglion synapses (Martin and Pilar, 1964b). This high safety factor, together with the electrical component of synaptic transmission, ensurcs that action potentials in the presynaptic elements invariably evoke action potentials in postsynaptic elements even at high stimulation frequencies. Integration does not occur at these synapses. Consistent with this finding, and in contrast to the results in choroid cells, we have not detected any slow synaptic potentials in ciliary neurons. Exogenous substance $P$ also 
had no effect on the membrane potential or input resistance of ciliary cells. We have verified this finding with three different modes of drug application.

We also did not detect any direct action of substance $P$ on nicotinic EPSPs evoked at low frequencies in ciliary neurons. Previous reports have described an inhibitory effect of substance $P$ on the responses to nicotinic agonists in bullfrog sympathetic (Akasu et al., 1983) and parasympathetic (Bowers et al., 1984) neurons, bovine chromaffin cells (Clapham and Neher, 1984), and cultured cells from chick ciliary and sympathetic ganglia (Margiotta and Berg, 1984; Role, 1984). Moreover, Role (1984) and Margiotta and Berg (1984) failed to detect any direct effect of substance P on membrane potential or input resistance in cultured ciliary ganglion neurons. One limitation of these studies is that, under conditions of dissociated cell culture, ciliary neurons cannot be distinguished from choroid neurons. The ciliary neurons, which in intact ganglia are larger than the choroid cells, may be preferentially impaled in culture. As we have shown, ciliary neurons in intact ganglia are unaffected by substance $P$. The expression of neurotransmitter receptors in dissociated neurons is strongly dependent on the culture conditions. Thus Crean et al. (1982) and Tuttle (1983) have found that cultured ciliary ganglion neurons lose their responsiveness to nicotinic agonists within 1 week unless they are co-cultured with myotubes or lysed membranes from myotubes. Similarly, Atweh and Yu (1983) have found that cultured mouse dorsal root ganglion neurons only express opiate receptors in the presence of a factor derived from glial cells. Thus, it is possible that the culture conditions of Role (1984) and Margiotta and Berg (1984) may not have allowed for the expression of substance $P$ receptors on choroid cells or, indeed, for the survival of choroid cells. An additional difference between the studies of Role (1984) and those reported here is that Role (1984) utilized whole cell recording techniques. It has recently been shown that M-currents may be diminished during whole cell clamp (Galvan et al., 1984). Thus, if the depolarizations we have seen are due to inhibition of the M-current, it is possible that they would not be detected by whole cell recordings.

Our failure to observe an effect of substancc $P$ on nicotinic transmission in ciliary neurons may reflect the low stimulus frequencies utilized $(0.5 \mathrm{~Hz})$. Higher stimulus frequencies may be required to release enough substance $P$ or acetylcholine to stabilize the desensitized state of the postsynaptic nicotinic receptors. For example, Bowcrs ot al. (1984) were able to observe inhibitory effects of substance $P$ on nicotinic EPSPs only at high stimulation frequencies. Unfortunately, the presence of presynaptic phenomena such as facilitation and depression at high stimulation frequencies (Martin and Pilar, 1964c) make such experiments in the ciliary ganglion difficult to interpret. Moreover, we have recently observed a direct depolarizing action of substance $\mathrm{P}$ on presynaptic calyces (Dryer and Chiappinelli, 1985) which further complicates this type of analysis.

The properties of choroid and ciliary neurons are thus highly divergent, despite their common embryological origin. This may be largely related to the different target tissues of the neurons. The smooth muscle choroidal coat of the retina is the target tissue of the choroid cells. In contrast, the ciliary cells innervate striated muscle, the only known autonomic ganglion neurons to do so. The striated iris muscle is capable of responding to high frequency stimulation (Pilar and Vaughn, 1969a, b) and, thus, is well matched with the ciliary neurons, which have a number of specializations allowing for high frequency synaptic transmission.

\section{References}

Adams, P. R., and D. A. Brown (1975) Actions of gamma-aminobutyric acid on sympathetic ganglion cells. J. Physiol. (Lond.) 250: 85-120.

Adams, P. R., and D. A. Brown (1980) Luteinizing hormone-releasing factor and muscarinic agonists act on the same voltage-sensitive $\mathrm{K}^{+}$-current in bullfrog sympathetic neurons. $\mathrm{Br}$. J. Pharmacol. 68: 353-355.
Adams, P. R., D. A. Brown, and S. W. Jones (1983) Substance P inhibits the M-current in bullfrog sympathetic neurones. Br. J. Pharmacol. 79: 330333.

Akasu, T., M. Kojima, and K. Koketsu (1983) Substance P modulates the sensitivity of the nicotinic receptor in amphibian cholinergic transmission. Br. J. Pharmacol. 80: 123-131.

Atweh, S. F., and R. Yu (1983) Development of opiate receptors on rat dorsal root ganglia in tissue culture: Role of glial cells. Soc. Neurosci. Abstr. 9: 847.

Bowers, C. W., L. Y. Jan, and Y. N. Jan (1984) Substance P-like peptide in preganglionic parasympathetic nerve terminals of the bullfrog. Soc. Neurosci. Abstr. 10: 1120 .

Brenner, H. R., and A. R. Martin (1976) Reduction in acetylcholine sensitivity of axotomized ciliary ganglion cells. J. Physiol. (Lond.) 260: 159-176.

Brown, D. A. (1983) Slow cholinergic excitation-a mechanism for increasing neuronal excitability. Trends Neurosci. 6: 302-307.

Cantino, D., and E. Mugnaini (1975) The structural basis for electrotonic coupling in the avian ciliary ganglion. A study with thin sectioning and freeze-fracturing. J. Neurocytol. 4:505-536.

Clapham, D. E., and E. Neher (1984) Substance P reduces acetylcholineinduced currents in isolated bovine chromaffin cells. J. Physiol. (Lond.) 347: 255-277.

Cowan, W., and E. Wenger (1968) Degeneration in the nucleus of origin of the preganglionic fibers to the chick ciliary ganglion following early removal of the optic vesicle. J. Expt. Zool. 168: 105-123.

Crean, G., G. Pilar, J. B. Tuttle, and K. Vaca (1982) Enhanced chemosensitivity of chick parasympathetic neurones in co-culture with myotubes. I Physiol. (Lond.) 331: 87-104.

Dodd, J., R. Dingledine, and J. S. Kelly (1981) The excitatory action of acetylcholine on hippocampal neurones of the guinea pig and rat maintained in vitro. Brain Res. 207: 109-127.

Dryer, S. E., and V. A. Chiappinelli (1983) Kappa-Bungarotoxin: An intracellular study demonstrating blockade of neuronal nicotinic receptors by a snake neurotoxin. Brain Res. 289: 317-321.

Dryer, S. E., and V. A. Chiappinelli (1985) Substance P depolarizes nerve terminals in an autonomic ganglion. Brain Res. 336: 190-194.

Dun, N. J., and S. Minota (1981) Effects of substance P on neurones of the inferior mesenteric ganglia of the guinea pig. J. Physiol. (Lond.) 321: 259271.

Erichsen, J. T., H. J. Karten, W. D. Eldred, and N. C. Brecha (1982a) Localization of substance P-like and enkephalin-like immunoreactivity within preganglionic terminals of the avian ciliary ganglion: Light and electron microscopy. J. Neurosci. 2: 994-1003.

Erichsen, J. T., A. Reiner, and H. J. Karten (1982b) Co-occurrence of substance P-like and leu-enkephalin-like immunoreactivities in neurones and fibres of avian nervous system. Nature 295: 407-410.

Galvan, M., L. S. Satin, and P. R. Adams (1984) Comparison of conventional microelectrode and whole-cell patch clamp recordings from cultured bullfrog ganglion cells. Soc. Neurosci. Abstr. 10: 146.

Ginsborg, B. L., C. R. House, and E. M. Silinsky (1974) Conductance changes associated with the secretory potential in the cockroach salivary gland. J. Physiol. (Lond.) 236: 723-731.

Hess, A. (1965) Developmental changes in the structure of the synapse on the myelinated cell bodies of the chicken ciliary ganglion. J. Cell Biol. 25. $1-19$.

Hess, A., G. Pilar, and J. N. Weakly (1969) Correlation between transmission and structure in avian ciliary ganglion synapses. J. Physiol. (Lond.) 202: 339354.

Jan, Y. N., and L. Y. Jan (1983) Coexistence and corelease of cholinergic and peptidergic transmitters in frog sympathetic ganglia. Fed. Proc. 42: 2929-2933.

Katayama, K., and S. Nishi (1982) Voltage-clamp analysis of peptidergic slow depolarizations in bullfrog sympathetic ganglion cells. J. Physiol. (Lond.) 333: '305-313.

Katayama, Y., R. A. North, and J. T. Williams (1979) The action of substance $P$ on neurones of the myenteric plexus of the guinea pig small intestine. Proc. R. Soc. Lond. (Biol.) 206: 191-208.

Landmesser, L., and G. Pilar (1970) Selective reinnervation of two cell populations in the adult pigeon ciliary ganglion. J. Physiol. (Lond.) 211: 203-216.

Landmesser, L., and G. Pilar (1972) The onset and development of transmis sion in the chick ciliary ganglion. J. Physiol. (Lond.) 222: 691-713.

Margiotta, J. F., and D. K. Berg (1984) Enkephalin and substance P modulate distinct synaptic properties of chick ciliary ganglion neurons. Soc. Neurosci. Abstr. 10: 805 
Martin, A. R., and G. Pilar (1963a) Dual mode of synaptic transmission in the avian ciliary ganglion. J. Physiol. (Lond.) 168: 443-463.

Martin, A. R., and G. Pilar (1963b) Transmission through the ciliary ganglion of the chick. J. Physiol. (Lond.) 168: 464-475.

Martin, A. R., and G. Pilar (1964a) An analysis of electrical coupling at synapses in the avian ciliary ganglion. J. Physiol. (Lond.) 171: 454-475.

Martin. A. R., and G. Pilar (1964b) Quantal components of the synaptic potential in the ciliary ganglion of the chick. J. Physiol. (Lond.) 175: 1-16.

Martin, A. R., and G. Pilar (1964c) Presynaptic and postsynaptic events during post-tetanic potentiation and facilitation in the avian ciliary ganglion. J. Physiol. (Lond.) 175: 17-30.

Marwitt, G., G. Pilar, and J. N. Weakly (1971) Characterization of two ganglion cell populations in avian ciliary ganglia. Brain Res. 25: 317-334.

Nishi, S., H. Soeda, and K. Koketsu (1965) Studies on sympathetic B and C neurons and patterns of preganglionic innervation. J. Cell. Comp. Physiol. 66: $19-32$
Otsuka, M., and S. Konishi (1983) Substance P-the first peptide neurotransmitter? I rends Neurosci. 6: 317-320.

Pilar, G., and J. B. Tuttle (1982) A simple neuronal system with a range of uses: The avian ciliary ganglion. In Progress in Cholinergic Biology: Model Cholinergic Synapses, I. Hanin and A. M. Goldberg, eds., pp. 213-247, Raven Press, New York.

Pilar, G., and P. Vaughan (1969a) Electrophysiological investigations of the pigeon iris neuromuscular junctions. Comp. Biochem. Physiol. 29: 51-72.

Pilar, G., and P. Vaughan (1969b) Mechanical responses of the pigeon iris muscle fibers. Comp. Biochem. Physiol. 29:73 87

Role, L. W. (1984) Substance P modulation of acetylcholine-induced currents in embryonic chicken sympathetic and ciliary ganglion neurons. Proc. Natl. Acad. Sci. U. S. A. 81: 2924-2928.

Tuttle, J. B. (1983) Interaction with membrane remnants of target myotubes maintains transmitter sensitivity of cultured neurons. Science 220: $977-$ 979 